\title{
Microwave synthesis of silver core-silica decorated nanoparticles
}

Edita Daublyte்,

Agnè Zdaniauskienè,

Tatjana Charkova*

Department of Organic Chemistry,

Center for Physical Sciences

and Technology,

3 Sauletekio Avenue,

10257 Vilnius, Lithuania
The silver nanospheres $(70 \pm 5 \mathrm{~nm})$ were synthesised and decorated with silica under microwave irradiation. The obtained silver core-silica decorated nanoparticles $(80 \pm 5 \mathrm{~nm})$ were applied for 4-mercaptobenzoic acid monolayer analysis by shell-isolated nanoparticle-enhanced Raman spectroscopy. A detailed protocol of synthesis, characterisation by UV/Vis, HR-TEM and Raman techniques are represented here.

Keywords: silver core-silica shell nanoparticles, shell-isolated nanoparticle-enhanced Raman spectroscopy, 4-mercaptobenzoic acid

\section{INTRODUCTION}

Silver and its compounds are widely used for wound healing in dermatology, dentistry, cardiology, cancer therapy, and other fields of biomedicine. A quickly progressing nanotechnology area made silver nanoparticles (Ag NPs) one of the most popular in recent decades. Due to their size, Ag NPs have increased antimicrobial activity against various bacteria, fungi and viruses. Moreover, Ag NPs are used in the textile, food, cosmetic industry; also, for optical limiters, touch screens, plasmonic, bio-sensing, and other devices 1-5].

A promising technique - surface-enhanced $\mathrm{Ra}$ man spectroscopy (SERS) - provides important information for studying complex systems. However, SERS application in bioanalysis poses several challenges, like biocompatibility and reliability [6]. Shell-isolated nanoparticle-enhanced Raman spectroscopy (SHINERS) helps to avoid the important limitation of the method [ [7, 8]. The inert shell $\left(\mathrm{SiO}_{2}, \mathrm{MnO}_{2}, \mathrm{TiO}_{2}\right.$, etc.) over the particles protects

\footnotetext{
* Corresponding author. Email: tatjana.charkova@ftmc.lt
}

from interaction with oxygen, environment, and analytes increasing stability and biocompatibility [9, 10]. Furthermore, the plasmonic property of silver is appropriate for the detection of various analytes using SERS. Silver has localised surface plasmon resonances that cover a convenient wavelength range (400-1000 nm), where most Raman measurements occur [11, 12. Consequently, silver nanoparticles covered by a thin layer of silica shell are one of the most popular for plasmonic sensing.

It is not very difficult to produce bare silver nanoparticles. The reduction by citrate, borohydride, ethylene glycol, or other agents is the most used chemical method [13]. However, further application of such Ag NPs is hampered by the presence of nonreacted reagents. Moreover, the washing procedure usually causes aggregation and degradation of the particles. Therefore, new, rapid and efficient synthetic methods for obtaining stable nanoparticles are still being investigated.

The physical, chemical, electrical and catalytic properties of nanoparticles depend on their size and shape. Therefore, shape-controlled synthesis requires specific conditions using physical, 
chemical, biological, microwave-assisted, and other techniques. The choice of reducer, stabilizer, solvent, and other chemicals allows producing diverse shapes of Ag NPs: nanospheres, nanocubes, nanorods, nanoprisms, nanowires, etc. [14, 15]. The angled nanostructures are welcomed in SHINERS experiments because they create greater Raman signal amplification [7]. The most used chemical method for shape-control is polyol synthesis, where a polyol acts as a solvent and reducer, and the polyvinylpyrrolidone (PVP) as a stabilizing and shape-controlling agent [16, 17]. Compared to reflux methods, microwave irradiation results in narrower size distribution and higher stability of nanoparticles in a shorter reaction time [18, 19]. Therefore, the polyol process is commonly used in the microwave-assisted synthesis of nanoparticles.

The main aim of this work was to synthesise angled silver core-silica shell nanoparticles suitable for SHINERS experiments. However, improved conditions of polyol synthesis under microwave irradiation allowed us to receive spherical silvercore nanoparticles decorated with silica bubbles (Ag@SiO 2 NPs). The specific nanoparticles were successfully used in SHINERS experiments with 4-mercaptobenzoic acid (4-MBA) as a model compound.

\section{EXPERIMENTAL}

\section{Materials}

The nanoparticles were synthesised using silver nitrate $\left(\mathrm{AgNO}_{3}, 99 \%\right)$, trisodium citrate dihydrate $\left(\mathrm{Na}_{3} \mathrm{Cit}, \mathrm{HOC}(\mathrm{COONa})\left(\mathrm{CH}_{2} \mathrm{COONa}\right)_{2} \cdot 2 \mathrm{H}_{2} \mathrm{O}, 99 \%\right)$, ethylene glycol (EG, $\mathrm{HOCH}_{2} \mathrm{CH}_{2} \mathrm{OH}, 99.5 \%$ ), polyvinylpyrrolidone (PVP, $\left(\mathrm{C}_{6} \mathrm{H}_{9} \mathrm{NO}\right)_{\mathrm{n}}$, average mol wt 40.000), hydrochloric acid ( $\mathrm{HCl}, 37 \%)$, (3-aminopropyl)triethoxysilane (APTES, $\mathrm{H}_{2} \mathrm{~N}\left(\mathrm{CH}_{2}\right)_{3} \mathrm{Si}\left(\mathrm{OC}_{2} \mathrm{H}_{5}\right)_{3}$, $99 \%)$ and sodium silicate solution $(10 \% \mathrm{NaOH}, 27 \%$ $\mathrm{SiO}_{2}$ ). The synthesis, analysis, and other experiments were carried out with the chemicals from Merck and in Milli-Q water $(18.2 \mathrm{M} \Omega \cdot \mathrm{cm})$. Raman measurements were performed on stainless steel substrate (Tienta SpectRIM) purchased from Merck.

\section{General equipment}

A microwave synthesizer CEM Discover SP was used for the microwave synthesis procedure. UV/ Vis spectra (200-1100 nm) were recorded on a Lambda 25 spectrophotometer. High-resolution transmission electron microscopy (HR-TEM) data were collected using a FEI Tecnai G2 F20 X-TWIN microscope. Raman and SHINERS spectra were recorded on a PerkinElmer RamanFlex 400 Echelle type spectrometer (excitation wavelength $785 \mathrm{~nm}$, $30 \mathrm{~mW}$ laser power; 10 scans with $10 \mathrm{~s}$ integration time).

\section{Synthesis of silver nanoparticles (Ag NPs)}

Freshly prepared $5 \mathrm{ml}$ of $10 \mathrm{mM} \mathrm{AgNO}, 5 \mathrm{ml}$ of $10 \mathrm{mM} \mathrm{Na}_{3}$ Cit, $0.5 \mathrm{ml}$ of EG, $5 \mathrm{ml}$ of $0.3 \mathrm{mM}$ PVP and $1 \mathrm{ml}$ of $0.02 \mathrm{mM} \mathrm{HCl}$ were mixed and stirred for $2 \mathrm{~min}$ at $20^{\circ} \mathrm{C}$. Then the reaction mixture was microwave heated at the power of $100 \mathrm{~W}$ to $60^{\circ} \mathrm{C}$ for $1 \mathrm{~min}$ with a holding time of $2 \mathrm{~min}$. On the second step, it was microwave heated to $95^{\circ} \mathrm{C}$ for $1 \mathrm{~min}$ and held at this temperature for $5 \mathrm{~min}$. Finally, the mixture was cooled to $50^{\circ} \mathrm{C}$ in the microwave synthesizer cooling system over $3 \mathrm{~min}$. Then it was left at $20^{\circ} \mathrm{C}$ for $30 \mathrm{~min}$. A yellow-green suspension of Ag NPs was obtained.

\section{Synthesis of silver core-silica decorated nanoparticles (Ag@SiO 2 NPs)}

To $7.5 \mathrm{ml}$ of Ag NPs suspension, $0.1 \mathrm{ml}$ of $1 \mathrm{mM}$ APTES was added and stirred at room temperature for $15 \mathrm{~min}$. Then $0.8 \mathrm{ml}$ of $0.54 \%$ sodium silicate solution was added and stirred for another $3 \mathrm{~min}$. The reaction mixture was placed in the microwave reactor and heated at the power of $100 \mathrm{~W}$ for two steps: to $60^{\circ} \mathrm{C}$ for $1 \mathrm{~min}$ with $0.5 \mathrm{~min}$ holding and $95^{\circ} \mathrm{C}$ for 1 min with 5 min holding. Next, the mixture was cooled to $50^{\circ} \mathrm{C}$ in the microwave reactor over $3 \mathrm{~min}$ and left at room temperature for $1 \mathrm{~h}$. A green-brown suspension of silver core-silica decorated nanoparticles was obtained, centrifuged (3500 $\mathrm{rpm} / 20 \mathrm{~min}$ ) twice, and washed with water. Concentrated Ag@SiO 2 NPs were transferred into a clean micro test tube and stored at $8-10^{\circ} \mathrm{C}$ in the dark.

\section{Raman and SHINERS measurements}

Synthesised $\mathrm{Ag} @ \mathrm{SiO}_{2}$ NPs were diluted with water (volume ratio 1:3). The solution $(2 \times 3 \mu \mathrm{L})$ was dropped onto a steel substrate and dried at room temperature. Then the Raman spectrum of $\mathrm{Ag} @ \mathrm{SiO}_{2}$ NPs was obtained. Next, the evaporated gold on a cleaned glass substrate was incubated in a 4-MBA $\left(5 \cdot 10^{-3} \mathrm{M}\right)$ alcohol solution for $1 \mathrm{~h}$. Then it was washed with alcohol and dried, and $\mathrm{Ag@SiO}{ }_{2} \mathrm{NPs}$ $(3 \mu \mathrm{L})$ were dropped onto a formed self-assembled 
monolayer of 4-MBA. Then, it was left to dry itself at room temperature. Next, the SHINERS spectrum of 4-MBA self-assembled monolayer was recorded.

\section{RESULTS AND DISCUSSION}

The shape and size of silver nanoparticles are possible to control in synthesised solutions by varying the temperature, the molar ratio of used reagents, and other experimental conditions. Ethylene glycol as both solvent and reducer helps to produce an angular particle shape. In the typical polyol synthesis, it is the most popular agent with a good solubility in water. Polyvinylpyrrolidone as a stabilizer helps to avoid the aggregation of nanoparticles and control the shape. It also serves as an additional reductant. Several other critical ingredients in the synthesis are chlorides and oxygen. These components initiate and affect oxidative etching, which results in sharp edges of nanostructures [20, 21].

Our experience in the microwave-assisted synthesis of silver nanoparticles [22] allowed using a simple precursor and reducer - silver nitrate and sodium citrate. The optimal molar ratio of the reagents $(10: 10 \mathrm{mM})$ was chosen by Faxian's protocol [23]. Because both salts are soluble in water, a mixture of ethylene glycol and polyvinylpyrrolidone in an aqueous medium was taken. After studying the literature, a strategy way to obtain as angular particles as possible was chosen (Fig. 1 b). The presence of $\mathrm{O}_{2}$ from air and $\mathrm{Cl}^{-}$ions in polyol synthesis causes the formation of etched spheres, sharp or truncated cubes, and nanowires [20]. Therefore, avoiding long uniform nanowires, we chose $\mathrm{HCl}$ as an etching agent and did not use an environment of nitrogen or other inert gas.

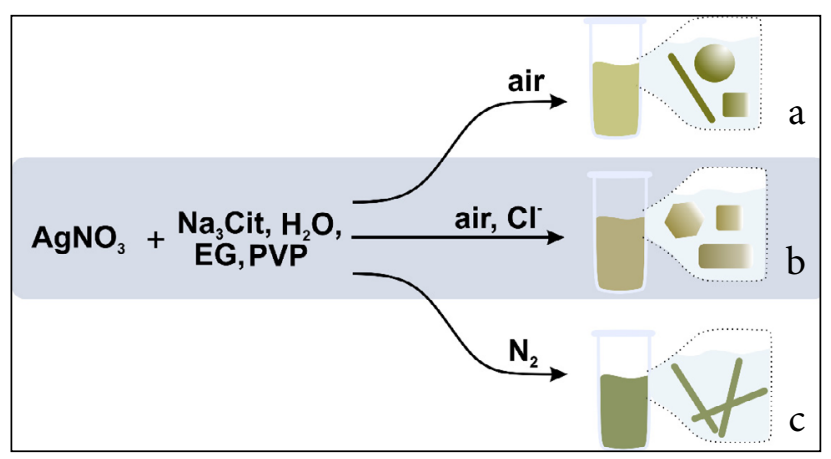

Fig. 1. The strategy of Ag NPs synthesis: resulting mixture of nanoproducts in the presence of air (a), in the presence of air and $\mathrm{Cl}^{-}$ions (b), and in the presence of inert $\mathrm{N}_{2}$ gas (c)
It is also well-known that the morphology and dimensions of the nanoproducts strongly depend on temperature and growth time. The polyol process reduction is carried out at the temperature higher than $150^{\circ} \mathrm{C}$ for $30 \mathrm{~min}$ or more [24. In our case, the aqueous medium limited the choice of temperature regime. Consequently, the Ag NPs synthesis time was achieved experimentally and provided under microwave irradiation in a boiling aqueous solution (Table 1). To maintain similar refluxing conditions, the temperature regime was broken down into stages, raising the temperature consistently. The length of each step was chosen according to the technical capabilities of the microwave reactor to raise the temperature evenly with a power of $100 \mathrm{~W}$. At higher power, particles were more likely to aggregate, and degradation occurred during synthesis. The $16-20^{\circ} \mathrm{C}$ primary temperatures were suitable, and using higher primary temperatures, the nanoparticles degraded during the synthesis. We also aimed to shorten the total synthesis time to get as stable products as it was possible.

Table 1. Conditions of Ag NPs microwave-assisted synthesis

\begin{tabular}{|c|c|c|c|}
\hline Stage & Temperature, ${ }^{\circ} \mathrm{C}$ & Time, min & $\begin{array}{l}\text { Power of microwave } \\
\text { reactor, } W\end{array}$ \\
\hline 1 & $20-60$ & 3 & 100 \\
\hline 2 & $60-95$ & 6 & 100 \\
\hline
\end{tabular}

The growth of nanoparticles was monitored by $\mathrm{UV} / \mathrm{Vis}$ technique. The UV/Vis absorption peak at $438 \mathrm{~nm}$ (Fig. 2a) and the visual exchange in colour from colourless to yellow-green suggest the formation of Ag NPs. After three days keeping at $8-10^{\circ} \mathrm{C}$, the exchange in colour from yellow-green to greyish was noticed. The beginning of Ag NPs aggregation was also improved by a specific UV/Vis spectrum (Fig. 20).

To increase stability, Ag NPs were covered with silica shell (Table 2) by the reported earlier procedure [22]. Ag NPs were not separate from the reaction mixture and were used for the silica coating procedure without any purification. Silica shell was formed over the nanoparticles in the presence of sodium citrate, ethylene glycol, polyvinylpyrrolidone, and $\mathrm{HCl}$ residues. HR-TEM images improved (Fig. 3), that $70 \pm 5 \mathrm{Ag}$ nanospheres were decorated with 


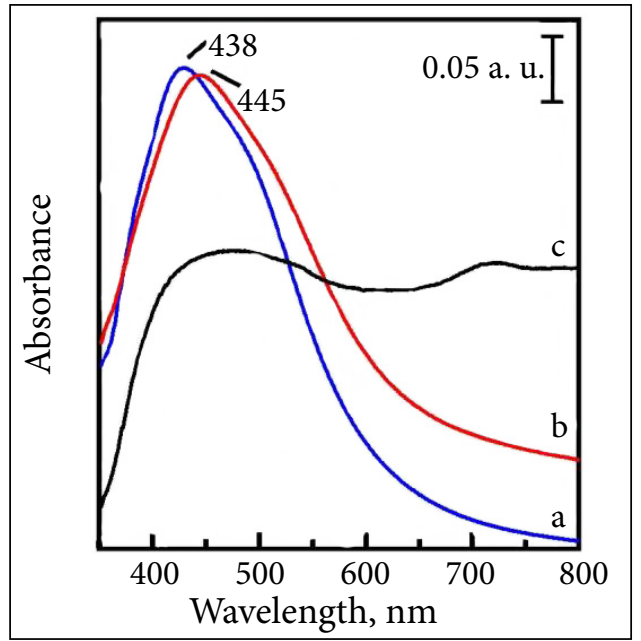

Fig. 2. UV/Vis spectra of Ag NPs (a), Ag@SiO NPs (b), and aggregated nanoparticles (c)

2-10 $\mathrm{nm}$ bubble silica shell. The green-brown suspension of synthesised $\mathrm{Ag} @ \mathrm{SiO}_{2} \mathrm{NPs}$ was stable keeping at $8-10^{\circ} \mathrm{C}$ for three weeks (Table 3 ). No changes in colour and UV/Vis spectrum were observed (Fig. 2b). After three weeks, a grey precipitate and changes in the UV/Vis spectrum occur.

Ta ble 2. Conditions of ${\mathrm{Ag} @ \mathrm{SiO}_{2}}_{2}$ NPs microwave-assisted synthesis

\begin{tabular}{c|c|c|c}
\hline Stage & Temperature, ${ }^{\circ} \mathbf{C}$ & Time, $\mathbf{m i n}$ & $\begin{array}{c}\text { Power of microwave } \\
\text { reactor, } \mathbf{W}\end{array}$ \\
\hline 1 & $25-60$ & 1.5 & 100 \\
\hline 2 & $60-95$ & 6 & 100 \\
\hline
\end{tabular}

Table 3. Experimentally obtained properties of the synthesised silver nanoparticles

\begin{tabular}{|c|c|c|}
\hline Obtained property & Ag NPs & $\mathrm{Ag} @ \mathrm{SiO}_{2} \mathrm{NPs}$ \\
\hline $\begin{array}{c}\text { Total time of formation } \\
\text { under MW }\end{array}$ & $9 \min$ & $\begin{array}{c}9 \min (\mathrm{Ag} \\
\mathrm{NPs})+7.5 \mathrm{~min} \\
\left(\mathrm{SiO}_{2}\right)\end{array}$ \\
\hline Colour & yellow-green & green-brown \\
\hline Form & nanospheres & $\begin{array}{c}\text { specific bubble } \\
\text { form }\end{array}$ \\
\hline Diameter & $70 \pm 5 \mathrm{~nm}$ & $80 \pm 5 \mathrm{~nm}$ \\
\hline Thickness of silica shell & - & $2-10 \mathrm{~nm}$ \\
\hline UV/Vis absorption peak & $438 \mathrm{~nm}$ & $445 \mathrm{~nm}$ \\
\hline $\begin{array}{l}\text { Stability keeping at } \\
\qquad 8-10^{\circ} \mathrm{C}\end{array}$ & 3 days & 3 weeks \\
\hline
\end{tabular}

It is well-known that larger than $50 \mathrm{~nm}$ nanospheres with a thin $2-4 \mathrm{~nm}$ inert shell allow obtaining more intensive Raman spectra of analytes [25.

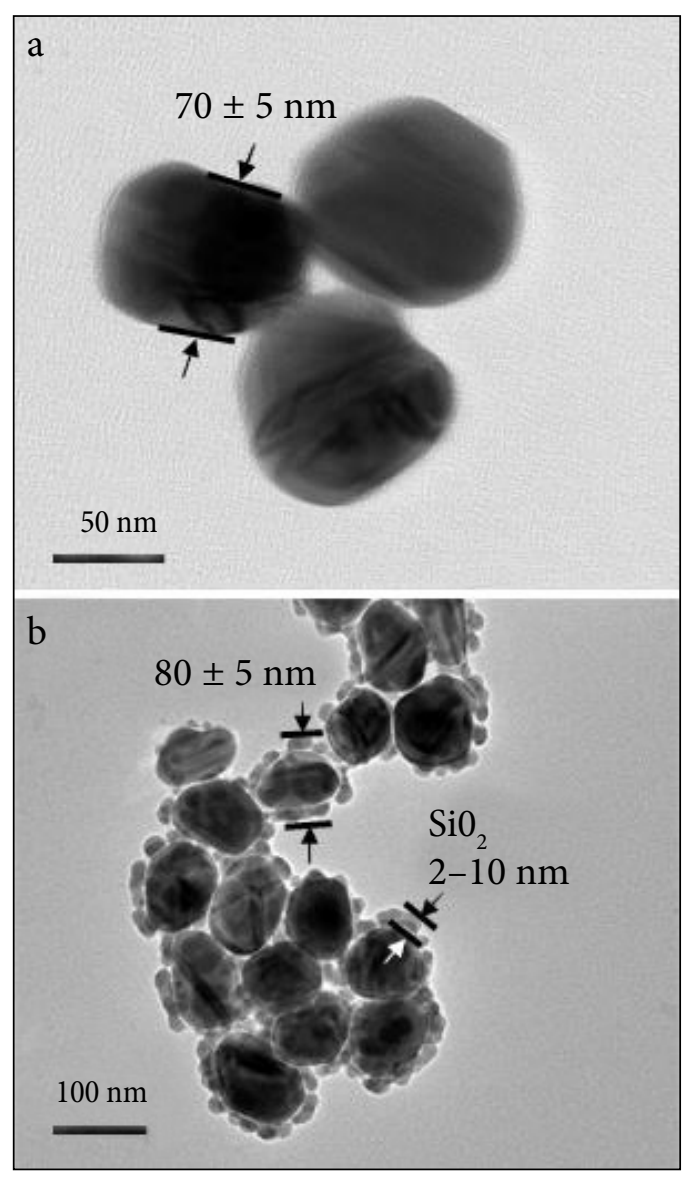

Fig. 3. HR-TEM images of Ag NPs (a) and $\mathrm{Ag} @ S i O_{2} \mathrm{NPs}_{\text {s }}(\mathrm{b})$

Synthesised Ag@SiO, NPs suited for SHINERS were $80 \pm 5 \mathrm{~nm}$ in diameter and protected by a 2-10 nm layer of silica.

For further experiments, a self-assembled monolayer of 4-MBA onto smooth gold was formed. The non-informative Raman spectrum of 4-MBA onto gold without nanoparticles was recorded (Fig. 4a). For comparison, the spectrum of stable Ag@SiO 2 NPs onto the steel substrate was recorded (Fig. 4b). The nanoparticles amplified contaminants from a nearby environment, but the intensity of the spectrum was very low. An enhanced SHINERS spectrum of 4-MBA was obtained with Ag@SiO ${ }_{2}$ NPs (Fig. 4c). All assignments of the spectrum were reported earlier [22] and are represented in Table 4.

We succeeded in producing silver core-silica decorated nanoparticles $(80 \pm 5 \mathrm{~nm})$ by rapid $(16.5 \mathrm{~min})$ microwave irradiation at atypical low temperatures $\left(95 \pm 5^{\circ} \mathrm{C}\right)$ for the polyol process. We failed to get angled nanostructures, but synthesised $\mathrm{Ag} @ \mathrm{SiO}_{2}$ NPs suitable for SHINERS experiments. In addition, stable particles were successfully isolated from 


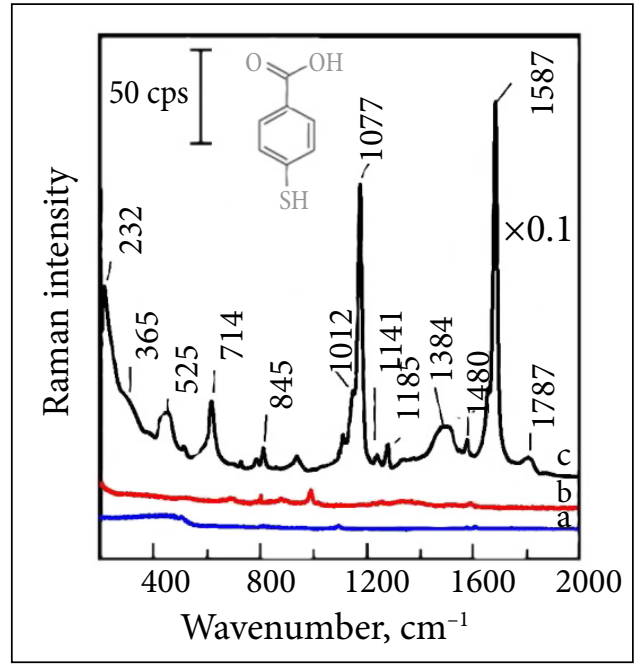

Fig. 4. Raman spectrum of 4-MBA adsorbed on a smooth Au surface without nanoparticles (a); Raman spectrum of Ag@SiO NPs onto steel substrate (b); SHINERS spectrum of 4-MBA on a smooth Au surface with $\mathrm{Ag} @ S i O_{2}$ NPs (c)

Table 4. SHINERS data of 4-MBA adsorbed on Au surface

\begin{tabular}{|c|c|}
\hline Assignments & $\Delta v, \mathrm{~cm}^{-1}$ \\
\hline Ring out-of-plane bending & 525 \\
\hline CCC out-of-plane bending & 714 \\
\hline $\mathrm{COO}^{-}$bending & 845 \\
\hline Ring breathing & 1012 \\
\hline $\begin{array}{l}\text { Ring breathing, C-S stretching, } \mathrm{C}-\mathrm{H} \text { symmetric } \\
\text { in-plane bending }\end{array}$ & 1077 \\
\hline $\mathrm{C}-\mathrm{H}$ bending & 1141 \\
\hline $\mathrm{C}-\mathrm{H}$ bending & 1185 \\
\hline $\mathrm{COO}^{-}$symmetric stretching & 1384 \\
\hline Ring bending & 1480 \\
\hline $\begin{array}{c}\text { Ring } \mathrm{C}-\mathrm{C} \text { stretching, } \mathrm{C}-\mathrm{H} \text { asymmetric in-plane } \\
\text { bending }\end{array}$ & 1587 \\
\hline
\end{tabular}

the reaction mixture by centrifugation and had low traces of impurities bands in the Raman spectrum. This opens up new possibilities for applying more widely the polyol process to synthesise stable coreshell particles of different shapes and forms.

\section{CONCLUSIONS}

Silver nanoparticles were synthesised by the modified polyol method and decorated with a silica shell. Both steps were performed under microwave irradiation without intermediate separation. Silver core-silica decorated nanoparticles were stable for up to 3 weeks and used for the analysis of a 4-MBA self-assembled monolayer by the SHINERS method.

\section{ACKNOWLEDGEMENTS}

This project has received funding from the $\mathrm{Eu}-$ ropean Social Fund (Project No. 09.3.3-LMTK-712-24-0187) under a Grant Agreement with the Research Council of Lithuania (LMTLT).

The authors acknowledge Algirdas Selskis for $\mathrm{Au}$ films preparation and Audrius Drabavičius for TEM recordings from the Department of Characterisation of Materials Structure of Center for Physical Sciences and Technology.

Received 4 October 2021 Accepted 27 October 2021

\section{References}

1. X. F. Zhang, Z. G. Liu, W. Shen, S. Gurunathan, Int. J. Mol. Sci. 17, 1 (2016).

2. A. C. Burdușel, O. Gherasim, A. M. Grumezescu, L. Mogoanta, A. Ficai, E. Andronescu, Nanomaterials 8, 681 (2018).

3. F. Paladini, M.Pollini, Materials 12, 1 (2019).

4. J. Talapko, T. Matijević, M. Juzbašić, A. AntolovićPožgain, I. Škrlec, Microorganisms 8, 1400 (2020).

5. S. J. Nurani, C. K. Saha, A. R. Khan, J. Electr. Electron. Eng. 10, 117 (2015).

6. C. Zong, M. Xu, L. J. Xu, et al., Chem. Rev. 118, 4946 (2018).

7. J. F. Li, Y. J. Zhang, S. Y. Ding, R. Panneerselvam, Z. Q. Tian, Chem. Rev. 117, 5002 (2017).

8. J. Krajczewski, A. Kudelski, Front. Chem. 7, 1 (2019).

9. H. B. Abdulrahman, J. Krajczewski, A. Kudelski, Appl. Surf. Sci. 427, 334 (2018).

10. T. Charkova, A. Zdaniauskienè, Chemija 31, 197 (2020).

11. B. Sharma, R. R. Frontiera, A. I. Henry, E. Ringe, R. P. Van Duyne, Mater. Today 15, 16 (2012).

12. R. Pilot, R. Signorini, C. Durante, L. Orian, M. Bhamidipati, L. Fabris, Biosensors 9, 1 (2019).

13. S. Iravani, H. Korbekandi, S. Mirmohammadiv, B. Zolfaghari, Res. Pharm. Sci. 9, 385 (2014).

14. C. M. Cobley, S. E. Skrabalak, D. J. Campbell, Y. Xia, Plasmonics 4, 171 (2009).

15. S. Mukherji, S. Bharti, G. Shukla, S. Mukherji, Phys. Sci. Rev. 4, 1 (2019).

16. J. Helmlinger, C. Sengstock, C. Groß-Heitfeld, et al., RSC Adv. 6, 18490 (2016).

17. B. Khodashenas, H. R. Ghorbani, Arab. J. Chem. 12, 1823 (2019).

18. M. Tsuji, ChemistrySelect 2, 805 (2017).

19. A. Kumar, Y. Kuang, Z. Liang, X. Sun, Mater. Today Nano 11, 100076 (2020). 
20. B. Wiley, T. Herricks, Y. Sun, Y. Xia, Nano Lett. 4, 1733 (2004).

21. B. J. Wiley, S. H. Im, Z. Y. Li, J. McLellan, A. Siekkinen, Y. Xia, J. Phys. Chem. B 110, 15666 (2006).

22. E. Daublytè, A. Zdaniauskienè, M. Talaikis, A. Drabavičius, T. Charkova, New J. Chem. 45, 10952 (2021).

23. L. Faxian, L. Jie, C. Xueling, Rare Metal Mat. Eng. 46, 2395 (2017).

24. Y. Sun, Y. Xia, Science 298, 2176 (2002).

25. J. F. Li, X. D. Tian, S. B. Li, et al., Nat. Protoc. 8, 52 (2013).
Edita Daublytè, Agnè Zdaniauskienè, Tatjana Charkova

\section{SILICIO DIOKSIDU DEKORUOTŲ SIDABRO} NANODALELIŲ MIKROBANGUৃ SINTEZE

Santrauka

Poliolių metodu susintetintos sidabro nanosferos (70 $\pm 5 \mathrm{~nm}$ ) buvo dekoruotos apsauginiu silicio dioksido sluoksniu $(2-10 \mathrm{~nm})$. Abu sintezès etapai atlikti veikiant mikrobangoms be tarpinio atskyrimo. Silicio dioksidu dekoruotos sidabro nanodalelès $(80 \pm 5 \mathrm{~nm})$ išliko stabilios tris savaites ir buvo sèkmingai pritaikytos 4-merkaptobenzoinès rūgšties monosluoksnio analizei, naudojant nanodalelių, padengtų apsauginiu sluoksniu, sustiprintos Ramano spektroskopijos metodą (angl. shell-isolated nanoparticle-enhanced Raman spectroscopy). Projektas bendrai finansuotas iš Europos socialinio fondo lèšu (projekto Nr. 09.3.3-LMT-K-712-24-0187) pagal dotacijos sutartį su Lietuvos mokslo taryba (LMTLT). 